\title{
Determination and assessment of essential elements in Acacia Nilotica-a medicinal and folk uses by different analytical methods
}

\author{
Magdy Diab Madbouly ${ }^{\mathrm{a}, \mathrm{c}^{*}}$, Mutaz Ezzeldien Salih ${ }^{\mathrm{b}, \mathrm{d}}$, Elmugdad Ahmed Ali ${ }^{\mathrm{d}}$, \\ Laila Tosson Kamel ${ }^{\mathrm{C}}$ \\ ${ }^{a}$ Department of Chemistry, Al Quwayiyah College of Science and Humanities, Shaqra University, KSA. \\ ${ }^{b}$ Department of Chemistry, Hurrymilla College of Science and Humanities, Shaqra University, KSA. \\ ${ }^{\mathrm{C}}$ The National Centre for Social and Criminological Research, Giza, Cairo, Egypt. \\ ${ }^{d}$ College Of Graduate Studies, Sudan University of Science \& Technology,Sudan.
}

\begin{abstract}
Acacia Nilotica is a good source of several nutrient elements essential for some metabolic processes. The pods of Acacia Nilotica collected from different areas in Sudan have been analysed for 6 minor ( $\mathrm{Li}, \mathrm{Na}, \mathrm{K}, \mathrm{Mg}, \mathrm{Ca}, \mathrm{P})$ and 3 trace (Fe, Zn, $\mathrm{Mn}$ ) elements by flame photometry and atomic absorption spectrophotometry using the standard addition and calibration curve methods, respectively. The phosphorous, however, was determined U.V. spectrophotometrically using the standard addition method for measurement of the absorbance, at $410 \mathrm{~nm}$ of the complex produced by the coupling of metamolybdate ammonium vanadate with phosphorous. The ash content, density, colour and $\mathrm{pH}$ were also determined by standard methods. The results obtained showed that acacia nilotica samples have been found to be especially rich in several nutrient elements such as, K, Fe and $\mathrm{P}$. Concentration of elements are discussed vis-à-vis their medicinal/therapeutic uses. Several statistics like PCA and correlation matrix between elements and pH were performed to the dataset in order to distinguish between geogenic enrichment, lithiogenic, and anthropogenic pollution elements found in the pods. The results suggested anthropogenic and geogenic origin of $\mathrm{Na}, \mathrm{Ca}, \mathrm{P}, \mathrm{Fe}, \mathrm{Zn}, \mathrm{Mn}, \mathrm{while} \mathrm{Li}, \mathrm{K}, \mathrm{Mg}$ showed lithogenic and/or geogenic origin and was associated and controlled by mixed origin.
\end{abstract}

Keywords: Acacia nilotica; minor and macro nutrient elements; photometric and AAS analysis; anthropotic and statistical analysis.

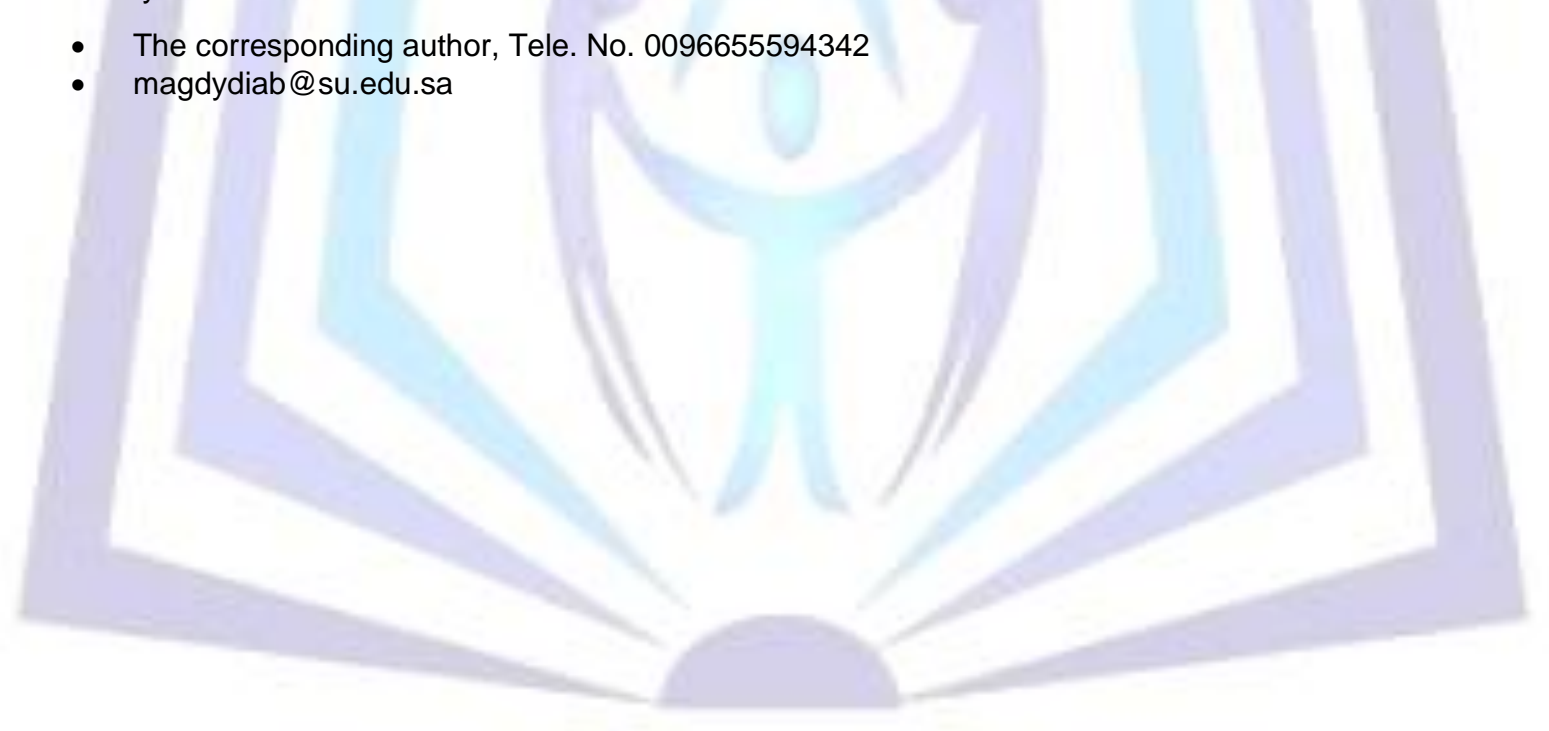

\section{Council for Innovative Research}

Peer Review Research Publishing System

\section{Journal: Journal of Advances in Chemistry}

\author{
Vol. 10, No. 2 \\ editorjaconline@gmail.com
}




\section{INTRODUCTION}

There are an increasing public interest and acceptance of natural therapies in developing and developed countries[1]. The world health organization (WHO) has declared that about $80 \%$ of the world's population, especially in developing countries, uses herbal medicine as their source of primary healthcare [2].The use of medicinal plants always plays an important role in African life where it constitutes a major source of therapy and healthcare needs in Africa. The traditions of collecting plants, processing herbal remedies and applying them have been handed down from generation to generation. African traditional medicine is the oldest and perhaps the most diverse of all medicine systems[3]. Acacia nilotica (Sunut in Arabic) is a member of subfamily mimosoideae of leguminous trees. The tree is readily distinguished by long white spines, yellow head inflorescence and grey necklace-like pods. It is a medium to large tree that can reach a height of $10 \mathrm{~m}$, with an average of 4-7 $\mathrm{m}$ in height. It is widely distributed in Africa from Egypt and Mauritania to south Africa especially in Sudan "Table 1",some sub species are wide spread in Asia as far east as Burma [4] "Fig 1".It is considered as a very important economic plant since early times as a source of tannins, gums, timber, fuel, folder and medicines. Acacia nilotica pods are used in treatment of wound, malaria, sore throat (aerial part) and toothache (bark)[5-8],while Gum Arabic is applied for kidney diseases treatment[9]. Most of the acacias produce tannins while acacia niloticaproduces more than $20 \%$ tannins, especially the inner bark which is used commercially for tanning and dyeing leather black in Sudan and Egypt [10]. Recently, acacia nilotica has been shown to affect central nervous system activities, in addition to their known antioxidant and anti-inflammatory activities these plants could provide novel poly-pharmacological leads of potential benefit to the treatment of Alzheimer's disease [11].The acacia nilotica pods are very characteristic, resembling a beaded necklace which are flat, straight or slightly curved, and fleshy when young with reddish hairs, becoming dark blackish when mature "Table 2". The pods aresweetly scented when crushed and contain a sticky fluid[12]. They have many biological activities including antihypertensive, antispasmodic[13]and mollusicidal properties [14]. Also, acacia nilotica pods are reported to be rich in polyphenols which decreases the blood glucose levels[15]and rich in tannins such as tannic acid which stimulates the transport of glucose and inhibits adipocyte differentiation [16,17]. Moreover, Egyptian Nubians believe that diabetics may eat unlimited carbohydrates as long as they also consume powdered pods [18]. Extracts from pods have demonstrated growth inhibition of at least four species of pathogenic fungi [19].Acacia nilotica is also a multipurpose legume which used for rehabilitation of dry land increases soil organic carbon, total and available forms of nitrogen and phosphorus under its canopy so it can be used in soil amelioration [20]. The quality of many medicinal plants depends on the concentration and type of minerals that they contain as play a very significant role, considering their curative properties against a variety of degenerative diseases. Several authors all across the world reported many studies on the important of elemental constituents of the herbal drug plants which enhances the awareness about trace elements in these plants [21].Because acacia nilotica globule heads are widely used as herbal medicine and its extract powder as smoke, a lot of data is available concerning its organic constituents [22],very little data is known about its inorganic components. The present study was carried out on acacia nilotica pods. The aim of this study was to establish detailed findings on the alkaline earth metals ( $\mathrm{Li}, \mathrm{Na}$ and $\mathrm{K}$ ), Alkali metals (calcium and magnesium), heavy metals (iron, manganese and zinc) and phosphorus in the pods selected in five different zones in Sudan with specific variation in soil. Acacia nilotica pods used for this study was based on their extensive use in traditional medicinal system of Sudan.

\section{Material and methods}

\subsection{Study area}

Five sites were chosen as source of samples, Elobied lies on the western part of Sudan (latitude $13^{\circ} \mathrm{N}$ and longitude $30^{\circ} \mathrm{E}$ ) with rainfall of about $600 \mathrm{~mm} /$ year and generally sandy clay loam soil, Gadarif state lies on the eastern part of Sudan, adjacent to Ethiopia, between latitude $12.4-15.4^{\circ}$ and longitudes $33.3-30.3^{\circ} \mathrm{E}$, the soils are deep dark colours, high clay content and strong vitriolic properties, Ad Damazim lies on the southern part of Sudan ( Latitudes $11.7891^{\circ} \mathrm{N}$ and Longitudes $34.359^{\circ} \mathrm{E}$ ), the soil consists of dark cracking clay (Vertisol) which extends to at least $15 \mathrm{~m}$ in depth, Abu Hamed lies on the northern part of Sudan (Latitudes $19^{\circ} 30^{\prime} \mathrm{N}$, and Longitudes $33^{\circ} 20^{\prime} \mathrm{E}$ ) between the 3rd and 5th cataracts in the River Nile and El Gazera state which lies on the central part of Sudan, The soil consists of dark cracking clay (Vertisol) which extends to at least $15 \mathrm{~m}$ in depth.

\subsection{Sample Digestion}

An accurate weight of dried, ground, fine powder pods was incinerated in a platinum crucible over the burner. The charred material was heated in muffle furnace for four hours and digested in (5:1) mixture of nitric acid and perchloric acid[21]. The solution was filtered over Whatman filter paper 40 and the volume was adjusted up to $100 \mathrm{ml}$ using de-ionized water. For lithium, sodium and potassium $1000 \mathrm{ppm}$ stock solution were prepared; $100 \mathrm{ppm}$ of lithium, sodium and potassium solutions were prepared from stock solution. After that the solutions were prepared in $50 \mathrm{ml}$ volumetric flask then emissions of the solutions were measured. The determination of magnesium and calcium was done by preparing 1,2 and $3 \mathrm{ppm}$ solution from $100 \mathrm{ppm}$ solution and diluted in $50 \mathrm{ml}$ volumetric flask then the emissions were read of standard solution and samples. Colorimetric procedures for the determination of phosphate utilizing the stable yellow colour which is developed when an excess of molybdate is added to an acidified solution of orthophosphate and vandate have been described. The method is quite free of interference. Possible interference from soluble silicate was studied at the concentration of nitric acid present during colour development, silica interference is negligible. The optical density at 430 $\mathrm{nm}$ of a solution containing $2 \mathrm{mg}$ of soluble silica per $100 \mathrm{ml}$ was studied with varying amounts of nitric acid added to it. 25 $\mathrm{ml}$ of the molybdivanadate reagent was added in each case. 


\subsection{Physico-chemical analysis}

It includes number of parameters like colour, $\mathrm{pH}$ and ash content. The colour differences of the pods is due to the differences in the tannin's contents of the pods according to different sites and this in accordance with Dilleman [23] which might be attributed to environmental modifications. The soil pH may influence nutrient absorption and plant growth in two ways either by direct effect of the hydrogen ion or indirect through its influence on nutrient availability. Measurements of $\mathrm{pH}$ were carried out on a Jenway $3505 \mathrm{pH}$-meter using a combined glass electrode. Solutions for measuring $\mathrm{pH}$ were prepared by weighing $0.1 \mathrm{~g}$ of dried, ground pods which was dissolved in a $100 \mathrm{ml}$ volumetric flask using double deionized water, filtered after 24 hours, then $\mathrm{pH}$ was measured. For ash content the charred material was heated in muffle furnace for four hours at $260^{\circ} \mathrm{C}$ and the crucible was cooled at room temperature in desiccator, weighted without delays to determine the ash content percentage.

\subsection{Quality control analysis}

Chemicals used for samples and standard solutions preparations were purchased from LOBA CHEMYE and Scott science. Standard solutions were prepared in double de-ionized water and used to calibrate the instruments. Precision and accuracy of analysis were checked through repeated analysis against NITS Standard Reference Material 1570A. A SHIMADZU U.V1800 ING200V UV-Visible double-beam spectrophotometer with matched 1-cm quartz cuvettes and a fixed slit width $(2 \mathrm{~nm})$ was used for all the absorbance measurements and treatment of data. The atomic absorption spectroscopy (AAS) measurements were determined by an air-acetylene flame atomic absorption spectrometer (Perkin Elmer 3110). Metal hollow cathode lamps specific for each metal, were used as radiation/sources and a JENWAY Clinical PFP7 flame photometer.

\subsection{Statistical analysis}

\subsubsection{Principal component analysis (PCA)}

PCA is a powerful analytical technique for pattern recognition that is designed to transform the original variables into new, uncorrelated variables (axes), called the principal components, which are linear combinations of the original variables. It extracts the eigenvalues and eigenvectors from the covariance matrix of original variables. The eigenvalues of the PCs are the measure of their associated variance, the participation of the original variables in the PCs is given by the loadings, and the coordinates of the objects are called scores [24-26]. PCA has been widely used to deliver more information on links among sampling sites, pollutant concentrations, correlation patterns, and latent factors responsible for the data-set structure in the environmental studies [27-30]. Principal component analysis (PCA), is generally employed to reduce the dimensionality of a data set while attempting to preserve the relationships present in the original data [31].

\subsubsection{Correlation Matrix}

Correlation can tell you something about the relationship between variables. It is used to understand whether the relationship is positive or negative and the strength of this relationship. Correlation is a powerful tool that provides these vital pieces of information. It is measured by what is called coefficient of correlation ( $r$ ). Its numerical value ranges from +1.0 to -1.0 . It gives us an indication of the strength of relationship. In general, $r>0$ indicates positive relationship, $r<0$ indicates negative relationship while $r=0$ indicates no relationship (or that the variables are independent and not related). Here $r=+1.0$ describes a perfect positive correlation and $r=-1.0$ describes a perfect negative correlation. Closer the coefficients are to +1.0 and -1.0 , greater is the strength of the relationship between the variables.

\subsubsection{Cluster analysis $(C A)$}

The purpose of cluster analysis is to identify groups or clusters of similar sites on the basis of similarities within a class and dissimilarities between different classes [32]. Hierarchical cluster analysis (HCA) examines distances between samples. The most similar points are grouped forming one cluster and the process is repeated until all points belong to one cluster $[33,34]$.The result obtained can be presented ina two-dimensional plot called dendrogram.

All multivariate statistical analyses, including principal component analysis (PCA) and correlation matrix (CM) were conducted using SPSS 16.0 for windows. For comparison of the heavy metal and pods data, statistical significance was computed by ANOVA. Differences are considered to be significant if $P<0.05[35,36]$. In order to look for a possible linear dependence between the different heavy metal homologues in pods samples, obtained heavy metals were tested for correlations between them using Pearson's correlation coefficient based on the assumption that the data were normally distributed.

\section{Results and discussion}

\subsection{Macronutrients (Li, $\mathrm{Na}, \mathrm{K}, \mathrm{Mg}, \mathrm{Ca}$, and $\mathrm{P}$ )}

A bar plot of macronutrients $(\mathrm{Li}, \mathrm{Na}, \mathrm{K}, \mathrm{Mg}, \mathrm{Ca}$ and $\mathrm{P})$ at $\mathrm{mg} / \mathrm{g}$ concentration in "Figure 3" shows little variations in elemental concentration except for $\mathrm{K}$, which vary in a wide range. The $\mathrm{K}$ concentration of all pods collected from different sites is much higher than that of all elements. Lithium is not known to be an essential plant nutrient but there is some evidence that $\mathrm{Li}^{+}$can affect plant growth and development. Due to lithium's small size and high charge density, it shares some properties with $\mathrm{Na}^{+}$[37]. Most metals interact with soil particles via cation exchange and possibly specific adsorption depending on their chemical properties. The biochemical mechanisms of action of lithium appear to be multifactorial and are intercorrelated with the functions of several enzymes, hormones and vitamins, as well as with growth and transforming 
factors[38]. $\mathrm{Li}^{+}$concentration varied from $0.143 \mathrm{mg} / \mathrm{g}$ for pods collected from the northern site to $0.966 \mathrm{mg} / \mathrm{g}$ for the pods collected from the eastern site. The highest mean Li content found in the Rosaceae family plants was about $2.9 \mathrm{mg} / \mathrm{kg}[39]$. The US Environmental Protection Agency (EPA) in 1985 estimated the daily Li intake of a $70 \mathrm{~kg}$ adult to range from 650 to $3100 \mu \mathrm{g}$ [40]. $\mathrm{Na}^{+}$concentration ranged from $0.081 \mathrm{mg} / \mathrm{g}$ in the pods collected from the northern site to $0.322 \mathrm{mg} / \mathrm{g}$ in those collected from the western site. Potassium in plants functions in protein synthesis, activation of enzymes, major solute functioning in water balance and thus affecting osmosis, operation of stomata. In animal, $\mathrm{K}$ has a diuretic nature while Na plays an important role in the transport of metabolites. The $\mathrm{K}^{+}$concentration ranged from $1.962 \mathrm{mg} / \mathrm{g}$ in the pods collected from the central site to $6.321 \mathrm{mg} / \mathrm{g}$ in those collected from the southern site. The ration of $\mathrm{K} / \mathrm{Na}$ in any food is an important factor in prevention of hypertension arteriosclerosis with $\mathrm{K}$ depresses and $\mathrm{Na}$ enhances blood pressure. A plot of $\mathrm{K} / \mathrm{Na}$ ratio showed that the highest $\mathrm{K} / \mathrm{Na}$ ratio was in pods collected from the southern site,39.25, followed by those collected from central site, 28.43, then those collected from the northern site,19.91, followed by those collected in the eastern site, 15.5, and the pods collected from southern site showed the lowest value 11.79. Results confirm that the consumption of Acacia nilotica pods cultivated in different Sudan sites, have contributed to the near complete absence of cases of high blood pressure. Magnesium plays an important role in plants, particularly into the seeds. It is also said to promote formation of oils and fats, possibly by increasing photosynthetic activity in the leaves. $\mathrm{Mg}^{++}$in animal is required in the plasma and extra cellular fluid where it helps in maintaining osmotic equilibrium in the body. Mg concentration varied from $0.870 \mathrm{mg} / \mathrm{g}$ for pods collected from northern site to $0.340 \mathrm{mg} / \mathrm{g}$ for pods collected from southern site.

Calcium is essential in plants for the formation and stability of cell walls and maintenance of membrane structure and permeability, activates some enzymes, regulate many responses of cells to stimuli. Calcium functions as a constituent of bones and teeth, regulation of nerve and muscle function. In blood coagulation, calcium activates the conversion of prothrombin to thrombin. "Table 3" shows that calcium concentration varied from $0.19 \mathrm{mg} / \mathrm{g}$ for pods collected from the southern site to $0.535 \mathrm{mg} / \mathrm{g}$ for the pods collected from the central site. Phosphorus is generally available in the soil as phosphate, an anion that is not bindable by the cation exchange complex and thus can be easily leached from the soil by rain or runoff [41]. Phosphorus is located in every cell of the body and is vitally concerned with many metabolic processes, including those involving the buffers fluids. Phosphorus concentrations varied from $1.555 \mathrm{mg} / \mathrm{g}$ for the pods collected from the northern sites to $2.442 \mathrm{mg} / \mathrm{g}$ for the pods collected from the central site. This may be due to the nature of the soil of central and northern sites that contain large amounts of clay which sorb more $P$ than those containing small amounts [42].There is definite relationship between calcium and phosphorus in the formation of bones and teeth and as the major structural elements of the skeletal tissue. Under conditions of salt restriction, calcium appears highly important in helping to maintain the potassium content of tissue [43]. A bar plot of $\mathrm{Ca} / \mathrm{P}$ ratio is shown in "Figure3 " the highest $\mathrm{Ca} / \mathrm{P}$ ratio was in pods collected from the northern site 0.232 , followed by those collected from central site, 0.219 , then those collected from the eastern site, 0.183 , followed by those collected in the western site, 0.172 , and the pods collected from southern site showed the lowest value, $0.082 \mathrm{mg} / \mathrm{g}$.

\subsection{Micronutrients (Fe, $\mathrm{Zn}$ and $\mathrm{Mn}$ )}

Bar plot of micronutrients ( $\mathrm{Fe}, \mathrm{Zn}$ and $\mathrm{Mn}$ ) in "Figure 3" shows little variation in elemental concentration except for Fe which vary in a wide range. Iron is a component of cytochromes, electron transport, activates some enzymes, plays a role in chlorophyll synthesis, where, it functions as haemoglobin in the transport of oxygen, in cellular respiration. Iron concentration varied from $2.988 \mathrm{mg} / \mathrm{g}$ for the pods collected from northern to $0.659 \mathrm{mg} / \mathrm{g}$ for the pods collected from the eastern site. The permissible limit of FAO/WHO [44, 45] in edible plants was $20 \mathrm{mg} / \mathrm{kg}$. Zinc is active in formation of chlorophyll, activates some enzymes, plays a role in formation of auxin, chloroplasts, and starch. Zn concentrations vary from $0.946 \mathrm{mg} / \mathrm{kg}$ for the pods collected from the eastern site to $0.893 \mathrm{mg} / \mathrm{kg}$, for the pods collected from the southern. "Table 3" shows that the differences in concentrations of zinc for the pods collected from different sites was very small compared to 27.4 ppm permissible limit set by FAO/WHO [45] in edible plants and this could be attributed that $\mathrm{Zn}$ has low mobility in soils [46] and has a tendency of being adsorbed on clay size particles[47]. Manganese is active in formation of amino acids, activates some enzymes, coenzyme activity, required for water-splitting step of photosynthesis, chlorophyll synthesis. Mn concentration varied from $0.418 \mathrm{mg} / \mathrm{g}$ in pods collected from the central site to $0.192 \mathrm{mg} / \mathrm{g}$ in pods collected from the eastern site. Mn was found below the permissible limit of $6.61 \mathrm{ppm}$ as suggested by WHO [44]. It is clear from the results at hand that the micronutrients iron, zinc and manganese concentrations in the acacia nilocita pods collected from the five sites of Sudan is below permissible limit set by FAO/WHO.

\subsection{Statistical data treatment}

\subsubsection{Correlation matrix analysis}

Correlation analysis of the total element contents and $\mathrm{pH}$ "Table 4" showed weak negative and positive correlation among $\mathrm{pH}$ and all the elements. Li showed moderate positive correlation among $\mathrm{Zn}(\mathrm{r}=0.637)$ and $\mathrm{P}(\mathrm{r}=0.762)$ and negative correlation among $\mathrm{Na}(r=-0.671)$ and $\mathrm{K}(r=-0.564)$, respectively. Na showed moderate correlation among $\mathrm{K}(r=0.572)$ and $\mathrm{Mg}(r=0.664)$ and negative correlation among $\mathrm{Fe}(r=-0.628)$ and $\mathrm{Zn}(r=-0.731)$, respectively. Ca moderately and positively correlated with $\mathrm{Fe}(r=0.714)$ and $\mathrm{Zn}(r=0.786)$ and strongly and negatively with $\mathrm{Mn}(r=-0.930)$. The relationships between the elements in the soils in the different area appear complex and difficult to explain individually. These strong correlations among metal-metal pair may be an indication of common sources of these metals as well as similar geochemical characteristics [48]. Other elements did not show any significant correlation among each other in the pods matrix suggesting different origin or dissimilar sediment-logical properties. All elements contents in pods do not correlate with $\mathrm{pH}$, owing to the narrow range of $\mathrm{pH}$ (3.6-5.1) measured. This means that $\mathrm{pH}$ has limited importance on the elements mobility and distribution [49].The correlation analysis showed significant differences in elements between sites 
for all pods samples which confirm their probable common natural or anthropogenic origin. More explanation can be enabled by PCA.

\subsubsection{PCA}

It was applied to the whole set of data, the concentration of each elements in the five studied area were treated as collective variables. PCA yielded three principal components with eigenvalues $>1$, they accounted for more than 83.939 $\%$ of the total variance. The components were rotated using Varimax rotation. "Table 5" gives the rotated loadings and communalities. The loadings having a greater than 0.5 are marked bold in the table. Factor analysis was used to give information about the distribution and source identification of element pollution based on eigenvalues[50,51]. The scores and loadings plots of PCA are presented in "Figure4" in order to have clear visualization of the data trends. Factor 1 explaining $47.852 \%$ of the total variance, was moderately and positively related to $\mathrm{Li}(0.637)$, strongly and positively related to $\mathrm{Ca}(0.879), \mathrm{Fe}(0.810)$ and $\mathrm{Zn}(0.987)$, moderately and negatively related to $\mathrm{Na}(-0.932), \mathrm{Mg}(-0.734)$ and to $\mathrm{Mn},(-0.793)$, (Table 5). The relation of these metals with PC1 can be indicated by their different natural sources lithogenic and /or geogenic, where $\mathrm{Ca}, \mathrm{Fe}, \mathrm{Zn}$ and $\mathrm{Mn}$ are well known to be geogenic [51-54]. Non-existence of any correlation of $\mathrm{P}$ "Table 4" with other metals except $\mathrm{Li}(\mathrm{r}=0.595)$ and its lower loading in PC1 "Table 5" indicates its lithogenic origin. The high negative correlation of Mn with $\mathrm{Ca}(r=-0.930), \mathrm{Fe}(r=-0.786)$ and $\mathrm{Zn}(r=-0.750)$ and the negative loading in PC1 can be explained by its different source and its chemical behaviour in soils, notably the formation of oxides onto which other elements are adsorbed [48]. The high loading of $\mathrm{Zn}$ on PC1 (0.987) indicates industrial or urban contribution (anthropogenic) and/or from parental rocks (geogenic).Factor 2 and 3 explaining 19.821 and $16.267 \%$ of the total variance respectively showed highly positive factor loading on $\mathrm{K}(0.845)$ and moderate negative loading on $\mathrm{Li}(-0.644)$ which may indicate the lithogenic and/or geogenic source, although these two factors are insignificant and represent the physicochemical source of the variability [49].

\subsubsection{Metals and pH grouping using hierarchical cluster analysis (HCA)}

Dendrogram is a branching diagram that represents the relationships of similarity among a group of entities. We can use a dendrogram to represent the relationships between any kinds of entities as long as we can measure their similarity to each other. In this dendrogram, "Figure 5", we have cut a text into 15 chunks (15 segments). The arrangement of the chunks or segments tells us which chunks or segments are most similar to each other. The lengthof the branch points indicates howsimilar or different they are from each other: The greater the branch, the greater the difference. There are two ways to interpret this dendrogram: in terms of large-scale groups or in terms of similarities among individual chunks. Results of HCA performed on the elements found in the studied areas are depicted in "Fig.5". To identify large-scale groups, we start reading from right to left, finding the branch points that are at middle levels in the structure. In this dendrogram Chunks $\mathrm{Li}$, $\mathrm{k}$ and $\mathrm{Mg}$ are more similar to each other in origin than they are to $\mathrm{Mn}, \mathrm{P}, \mathrm{Zn}, \mathrm{Ca}, \mathrm{Fe}$ and $\mathrm{Na}$. Going more from the middle level to the left, chunks $\mathrm{pH}$ is linked with all elements. If we are trying to identify which individual segments are most similar to each other, we read the dendrogram from left to right (bottom of the dendrogram), identifying the first clades to join together as we move fromleft to right. The connection between $\mathrm{Li}$ and $\mathrm{K}, \mathrm{Mg}$ and the southern site is the closest link to the bottom of the diagram. Therefore they are most similar and join together first in the branching diagram and similarly clusteredthan they are to any other chunks. Moreover, the cluster comprised of western and central sites is linked with the first cluster. In the third cluster $\mathrm{pH}$, northern and eastern are very well linked. The fourth cluster comprised of $\mathrm{Mn}, \mathrm{P}$ and $\mathrm{Zn}$ but is also linked with $\mathrm{Ca}, \mathrm{Fe}$ and $\mathrm{Na}$. The longer of the horizontal lines indicates the degree of difference between branches, the longer the line, the greater the difference. The branch points that are at high levels in the structure indicate that chunks $\mathrm{Li}, \mathrm{K}, \mathrm{Mg}$, southern, western and central areas are not associated with $\mathrm{Mn}, \mathrm{P}, \mathrm{Zn}, \mathrm{Ca}, \mathrm{Fe}$ and $\mathrm{Na}$. The elements $\mathrm{Li}, \mathrm{K}, \mathrm{Mg}$ clusters may be lithogenic and/or anthropogenic, while the elements $\mathrm{Mn}, \mathrm{P}, \mathrm{Zn}, \mathrm{Ca}, \mathrm{Fe}$ and $\mathrm{Na}$ clusters may represent the mixed origin ( anthropogenic and geogenic) and /or be present under natural condition. Correlation analysis mentioned earlier supports the results of cluster analysis. From the results, a strong evidence of mutual dependence of these elements in the acacia nilotica system is anticipated.

\section{Conclusion}

The concentrations of 6 minor and three trace elements were determined in acacia niloticaby flame photometry and atomic absorption spectrophotometry, respectively using the standard addition and calibration curve methods.. The ranges of elemental concentrations have been found to vary in a wide range of $\mathrm{mg} / \mathrm{g}$ in all the samples except $\mathrm{K}$. It has been observed that acacia nilotica is enriched in $\mathrm{K}$, especially grown in southern area $(6.321 \mathrm{mg} / \mathrm{g})$, Fe, especially grown in southern and northern areas $(2.988 \mathrm{mg} / \mathrm{g})$ and $\mathrm{P}$,especially grown in southern area $(2.442 \mathrm{mg} / \mathrm{g})$. Further, the highest $\mathrm{K} / \mathrm{Na}$ ration changes in a wide range 20.6 (central site) to 4.0 (southern site). The highest $\mathrm{Ca} / \mathrm{P}$ ration ranged from 0.239 (northern site) to 0.103 (southern site). The statistical data obtained revealed that the concentrations of the elements in the pods are strongly affected by the characteristics of the soil in the studied areas. The results also suggest anthropogenic and/or geogenic origin of $\mathrm{Na}, \mathrm{Ca}, \mathrm{P}, \mathrm{Fe}, \mathrm{Zn}$ and $\mathrm{Mn}$, while lithogenic and geogenic of $\mathrm{Li}, \mathrm{K}$ and $\mathrm{Mg}$. When compared to estimated daily intake values, the elements concentrations did not exceed the limits in all of the studied areas. This means that the daily intake of these elements from the pods and their possible role in the body system are safe. 


\section{REFERENCES}

[1] Gurib-Fakim, A., 2006. Medicinal plants: traditions of yesterday and drugs of tomorrow. J. of Molecular Asp. of Med. 27(1),1-8.

[2] Mbatchoul, V.C., Ayebila1 A.J., and Apea1, O.B. 2011. Antibacterial activity ofphytochemicalsfrom acacia nilotica, entadaafricana and mimosa pigra L. on salmonella typhi. J.of Animal \&Plant Sciences. 10, 1,1248-1258.

[3] Calixto,J. B., 2005.Twenty five years of research on medicinal plants in Latin America:a personal review. J. Of Pharmacy and Pharmacology, 3(10).469-475.

[4] Brenan, J.P.M.,. 1983. Manual on taxonomy of acacia species: present taxonomy of fourspecies of Acacia (A.albida, A. Senegal, A. nilotica, A. Tortilis). FAO, Rome, 20-24.

[5] Swarbrick, J.T., 1997. Weeds of the pacific islands. Technical paper no. 209. South Pacific Commission, Noumea, New Caledonia, 124.

[6] Duke, J.A., 1983. Medicinal plants of the Bible. Trado-Medic Books, Owerri, NY

[7] Shetty, K. A. B., 1977. Indian Farming, 26(11), 82.

[8] Joshi P,. 1994. Ethnomedicine of tribal rajasthan - An overview; In: Pushpangadanetal. (Eds.), Gilmpses of Indian Ethnopharmacology, TBGRI, Thiruvunanthapuram, India, 147-162.

[9] Jain, A., Katewa, S. S., Galav, P. K., and Sharma, P. 2005. Indian J.Ethnopharmacol., ,102(2), 143-157.

[10] Kubmarawa, D., Ajoku, G. A., Enwerem, N. M. and Okorie, D. A. 2007. Afr. J.Biotechnol, 6(14), 1690-1696.

[11] Elkhalifa, K. F. 1996. Forest Botany, Khartoum University Press, 79-94.

[12] Sahni, M. 1968.Important Trees of the Northern Sudan, Khartoum University Press, 40-63.

[13] Catherine, M. C. and Okello, E.J. 2009. Kinetics of acetylcholinesterase inhibitoryactivities by aqueous extracts of Acacia nilotica, J. of Elemental analysis of some medicinal plants used in traditional medicine by atomicabsorption spectrophotometer (AAS),J. of Medicinal Plants Research, 4(19),1987-1990.

[14] Kiran, B., and Bargali,S.S. 2009. Acacia nilotica: a multipurpose leguminous plant,Nature and Science, 7(4). 230-241.

[15] Archa V., Navneet, P. and Avnish C. 2010. Physico-chemical analysis of ash of some medicinal plants growing in Uttarakhand, India. Nature and Science .8(6), 55-61.

[16] Zafar, M., Khan, M. A., Ahmad, M.G., Jan, S.,Sultana, K.,Ullah, S. K.Marwat, F.,Ahmad, A., Jabeen, A.,Nazir, A., Abbasi,M., Rehman,M., and Ullah, Z.2010. Ethnopharmacology.100,1-2, 131-134.

[17] Haq, F., Rahman,S., Ahmad, H., Iqbal, Z., and Ullah. R. 2012. Elemental analysis of paeoniaemodi and punica granatum by atomic absorption spectroscopy. American J. of Biochemistry, 2(4): 47-50.

[18] Rabia, N., Khan,M.,A., Kiran Y., Khan, M., Ahmad, B., Ali, P., Mazari, M., Mustafa,H. and Ahmad,H. 2012. Element content of some ethno medicinal ziziphuslinn.species using atomic absorption spectroscopytechnique, J. of Appl. Pharmaceuticalscience, 02 (03); 96-100.

[19] Shah, K. V., Kapupara, P. K., Desai, T.R. 2011.Determination of sodium, potassium , calcium and lithium in a wheatgrass by flame photometry. Pharma science monitor, 2, (3), 180-187.

[20] Mahmood, A., Sadia, R., Riffat, N.2013.Determination of toxic heavy metals in indigenous medicinal plants used in Rawalpindiand Islamabad cities, Pakistan. J.ofEthnopharmacology, 148,1, 158-164.

[21]Sadia W., Muhammad Imran Din, ,SairaNasir, Atta Rasool. 2012.Evaluation of Acacia nilotica as a nonconventional low cost biosorbent for theelimination of $\mathrm{Pb}(\mathrm{II})$ and $\mathrm{Cd}(\mathrm{II})$ ions from aqueous solutions, Arabian J. of Chemistry, in press.

[22] Dilleman, G. 1960.ladifferentiatonchemique infra specifique , Plantamedica ,8, 263-274.

[23] Helena, B., Pardo, R., Vega, M., Barrado, E., Fernandez, J.M., Fernandez, L., 2000.Temporal evolution of groundwater composition in an alluvial aquifer (Pisuerga River, Spain) by principal component analysis. Water Res. 34, 807-816.

[24] Wunderlin, D.A., Diaz, M., Ame, M.M.V., Pesce, S.F., Hued, A.C., Bistoni, M., 2001. Pattern recognition techniques for the evaluation of spatial and temporal variations inwater quality. A case study: Suquia River basin (CordobaArtgentina). Water Res. 35,2881-2894.

[25] Heberger, K., Milczewska, K., Voelkel, A., 2005. Principal component analysis ofpolymer-solvent and fillersolventinteractions by inverse gas chromatography. Colloids Surf., A 260, 29-37.

[26] Qu, W., Kelderman, P., 2001. Heavy metal contents in the Delft canal sediments and suspended solids of River Rhine: multivariate analysis for source tracing. Chemosphere 45, 919-925. 
[27] Goloboc`anin, D.D., Škrbic' , B.D., Miljevic' , N.R., 2004. Principal component analysis for soil contamination with PAHs.Chemometr.Intell. Lab. Syst. 72, 219-223.

[28] Singh, K.P., Malik, A., Mohan, D., Sinha, S., 2004. Multivariate statistical techniques for the evaluation of spatial and temporal variations in water qualityofGomti River (India)—a case study. Water Res. 38, 3980-3992.

[29] Yalcin, M.G., Narin, I., Soylak, M., 2008. Multivariate analysis of heavy m contents of sediments from Gumusler creek, Nigde, Turkey. Environ. Geol. 54, 1155-1163

[30] Moller, A., Muller, H.W., Abdullah, A., Abdelgawad, G., Utermann, J., 2005. Urban soilpollution in Damascus, Syria: concentrations and patterns of heavy metals in the soilsof the Damascus Ghouta. Geoderma 124, 63-71.

[31] Sparks, T., 2000. Statistics in Ecotoxicology. Wiley, Chichester, 320-330. [32]Danielsson, A., Cato, I., Carman, R., Rahm, L., 1999. Spatial clustering of metals in the sediments Skagerrak /Kattegat. Appl. Geochem. 14, 689-706.

[33] Birth, G., 2003. A scheme for assessing human impacts on coastal aquatic environments using sediments. In: Wood coffee, C.D., Furness, R.A., (Eds.), Coastal GIS.

[34] Chen, T.B., Wong, W.J.C., Zhou, H.Y., Wong, M.H., 1997. Assessment of trace metaldistribution and contamination in surface soil of Hong Kong. Environmental Pollution, 96, 61-68.

[35] Garcia, R., Millan, E., 1998. Assessment of Cd, Pb and Zn contamination in roadsidesoils and grasses from Gipuzkoa (Spain). Chemosphere 37 (8), 1615-1625.

[36] Alloway, B.J. 2008. Zinc in soils and crop nutrition. International fertilizer industryassociation and international zinc association, Brussels, Belgium and Paris $135-145$.

[37] Wiberg, E., Wiberg, N., and Holleman, A.F. 2001. Inorganic Chemistry.Academic press: San Diego, California.

[38] Darinka G., Kadifkova-Panovska,T., Ba eva, K. and Traj e Stafilov.2011. Metallic traceelements in medicinal plants from macedonia, Middle-East, J. of Scientific Research , 7 (1): 109-114.

[39] Kabata-Pendias, A. and Pendias, H. 1992. Trace elements in soils and plants, 2ed.CRC Press Inc, Boca Raton, Florida, USA.

[40] Saunders, D.S., 1985. Letter: United States Environmental Protection Agency. Officeof Pesticide Programs.

[41] Wiedenhoeft A.C. 2006. Plant nutrition. Hopkins WG (eds) the green world, Chelsea House publisher, New York NY.16-43.

[42] Solis, P. and Torrent, J. 1989. Phosphate Sorption by Calcareous Vertisolsandlnceptisols of Spain. Soil Sci. Soc. Am. J., 53: 456-459.

[43] Hays, V.W., Swenson, M. J. 1985. Minerals and Bones. In: Dukes'Physiology of domestic animals, Tenth edition, 449-466.

[44] WHO (World Health Organization). 1996. Guidelines for drinking water quality. Health criteria and other supporting information. 94/9960-Mastercoml Wiener Verlag-800,Australia.

[45] FAO/WHO. Contaminants. In: Codex Alimentarius (1st ed, XVII),FAO/WHO, CodexAlimentarius Commission: Rome. 1984.

[46] Chesworth, W. 1991. Geochemistry of micronutrients. In: Mortvedt, J.J. Cox, F.R.Shuman, L.M. and Welch R.M. (eds). Micronutrients in agriculture, 2nd edition. Soilscience society america. Inc. Madison Wisconsin.427 - 476.

[47] Al-Khashman O.A., Shawabkeh R.A., (2006). Metals distribution in soils around thecement factory in southern Jordan. Environ Pollut. 140,387-394.

[48] Chabukdhara ,M.,Nema, A. K. 2012. Assessment of heavy metal contamination inHindon River sediments: A chemometric and geochemical approach, chemosphere, 87, 945-953.

[49] Han, Y., Du, P., Cao, J., Posmentier, E.S., 2006. Multivariate analysis of heavy metalContamination in urban dusts of Xi'an, Central China. Science of the TotalEnvironment, 355, 176-186.

[ 50] Mico, C., Recatala, L., Peris, M., Sanchez, J., 2006. Assessing heavy metal sourcesin agricultural soils of an European Mediterranean area by multivariate analysis.Chemosphere 65, 863-872.

[51] Hanesch, M., Scholger, R., Dekkers, M., 2001. The application of fuzzy c-meanscluster analysis and non-linear mapping to a soil data set for the detection of pollutedsites. Physics and Chemistry of the Earth-Part A: Solid Earth and Geodesy 26, 885-891.

[52] Brumelis, G., Lapina, L., Nikodemus, O., Tabors, G., 2002. Use of the O horizon offorest soils in monitoring metal deposition in Latvia. Water Air \& Soil Pollution.135,291-309.

[53] Bai, J., Cui, B., Yang, Z., Xu, X., Ding, Q., Gao, H., 2010a. Heavy metal contaminationof cultivated wetland soils along a typical plateau lake from southwest China.Environmental Earth Science 59 (8), 1781-1788. 